\title{
Herbs and Spices in the Florida Garden ${ }^{1}$
}

\author{
Mary Salinas, Sydney Park Brown, and James M. Stephens ${ }^{2}$
}

This publication is intended for home gardeners interested in growing common culinary herbs and spices used to flavor food.

Herbs are the leaves of plants, while spices come from nonleafy parts like seeds, berries, roots, and bark. Some plants are considered both an herb and a spice. For example, the leaves of cilantro and dill are herbs, while their seeds are used as spices (e.g., coriander and dill seed).

Many common herbs and spices grow in Florida as warmor cool-season annuals or as long-lived perennials (Table 1). Florida's hot, humid, and rainy climate determines their lifespan. In other words, a perennial herb in other states or countries may only survive as a short-lived annual in Florida, and vice-versa. Performance can vary even within the state from north to south Florida.

\section{Location and Soil Preparation}

Locate herbs and spices where they can be conveniently accessed for use. Herbs and spices are often grown in a vegetable or herb garden (Figure 1). However, the appealing foliage and flowers of many herbs and spices also make them attractive additions to flower beds and containers. Herbs in the Apiaceae plant family (e.g., dill, parsley, fennel) are good additions to butterfly gardens because they provide food for the caterpillars of black swallowtail butterflies (see Table 1). Note that some herbs, especially mints, tend to proliferate and become weedy if allowed to grow unchecked.

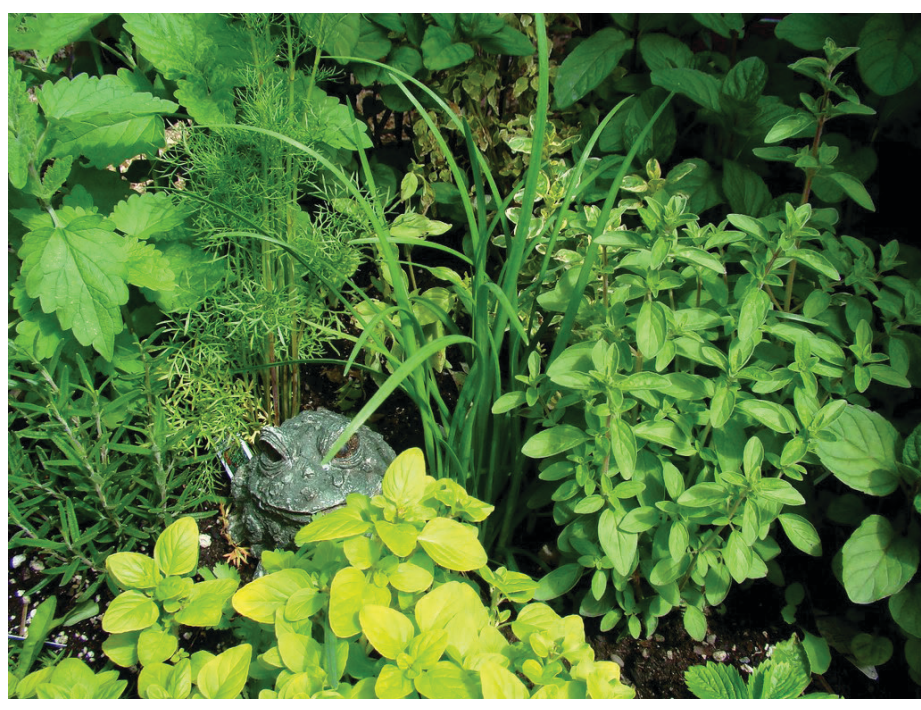

Figure 1. Herb garden.

Credits: Amanda Kae's Photos-Licensed by CC BY 2.0 (https:// search.creativecommons.org/photos/c2cef178-abcc-4aec-9f8ad3b8f715be65)

Growing herbs in containers (Figure 2) offers numerous advantages. The potting soil can be customized as needed, the pots can be moved to adjust for seasonal shifts in sunlight and temperature, and unruly herbs like mints can be restrained.

When growing perennial herbs such as rosemary in a vegetable garden, group them where they will not be disturbed when the rest of the garden is prepared for replanting. Likewise, consider establishing a dedicated area for annual herbs and spices that reseed, such as basil.

1. This document is CIR570, one of a series of the Horticultural Sciences Department, UF/IFAS Extension. Original publication date March 1994. Revised March 1998 and December 2021. Visit the EDIS website at https://edis.ifas.ufl.edu for the currently supported version of this publication.

2. Mary Salinas, MS, Extension agent II, residential horticulture, UF/IFAS Extension Santa Rosa County; Sydney Park Brown, associate professor emeritus, Environmental Horticulture Department; and James M. Stephens, professor emeritus, Horticultural Sciences Department; UF/IFAS Extension, Gainesville, FL 32611.

The Institute of Food and Agricultural Sciences (IFAS) is an Equal Opportunity Institution authorized to provide research, educational information and other services

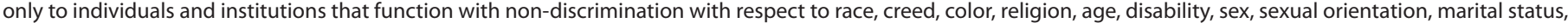

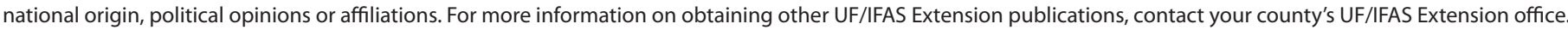
U.S. Department of Agriculture, UF/IFAS Extension Service, University of Florida, IFAS, Florida A \& M University Cooperative Extension Program, and Boards of County Commissioners Cooperating. Andra Johnson, dean for UF/IFAS Extension. 


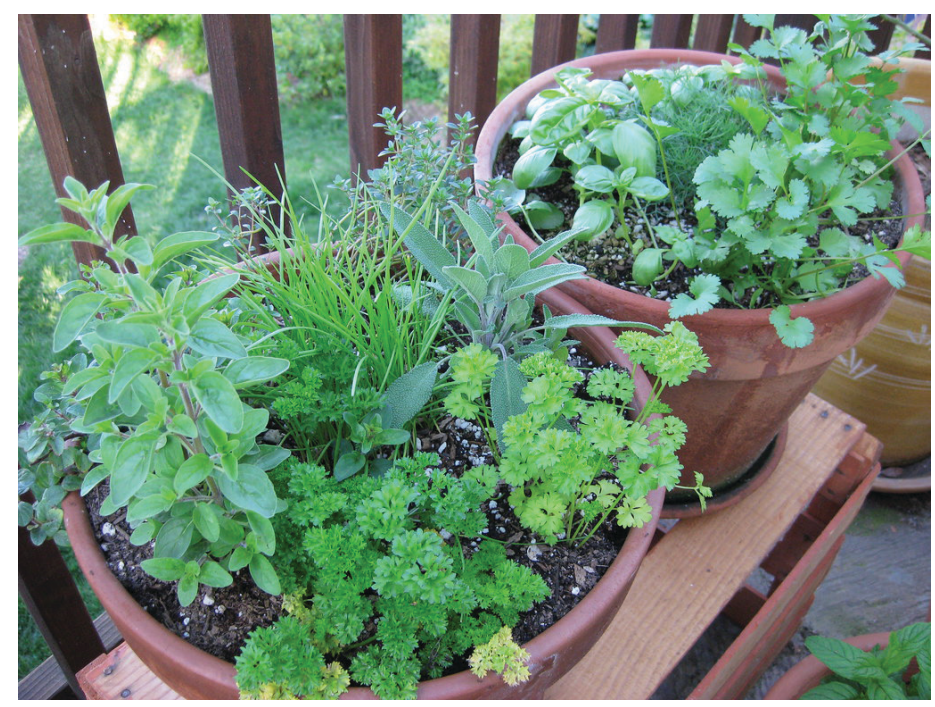

Figure 2. Potted herbs growing on a balcony. Credits: Thomas Pix —Licensed by CC BY 2.0 (https://search. creativecommons.org/photos/b327eecb-ef7a-4fed-bbc562ab0dad06bf)

In general, most herbs/spices will grow satisfactorily under the same conditions as vegetables, that is, ample sunlight and well-drained soil. However, some herbs have different fertilizer and watering needs than vegetables. For example, sage, rosemary, and thyme require soil on the drier side, whereas parsley, chervil, and mint grow best with considerable moisture. Group herbs with similar water needs together. The addition of organic matter to sandy soil is particularly beneficial to herbs that prefer moist soil. Refer to the Florida Vegetable Gardening Guide for additional cultural information: https://edis.ifas.ufl.edu/publication/ vh021.

\section{Propagation}

Typically, only one plant (or just a few) of a particular herb or spice is needed. Of course, this depends on its life cycle (annual or perennial), the mature size, and the culinary demand for it. Plants can be purchased at garden centers or mail-ordered, or gardeners can propagate them from seeds, cuttings, or division (Figure 3).

\section{Seed}

Starting herbs from seed allows the herb gardener to grow varieties that are not readily available in local garden centers. The planting depth is usually listed on the seed packet, or you can use this rule of thumb: plant no deeper than twice the diameter of the seed. Tiny seeds can be pressed into the soil and lightly covered. Seeds can be directly seeded into the garden or started in containers; plant at 2-3 week intervals to ensure a continuous harvest.

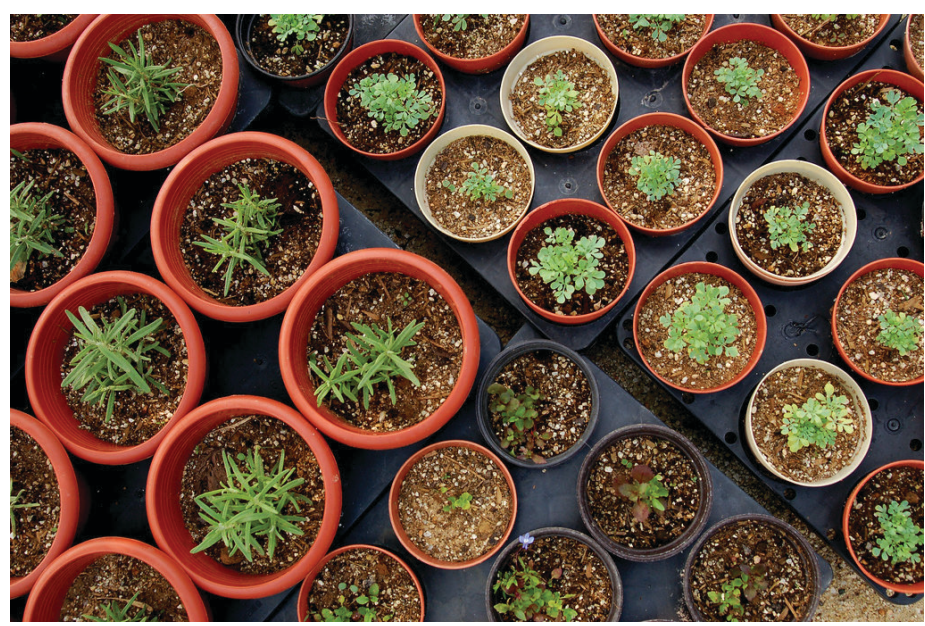

Figure 3. Propagating herbs from cuttings (left) and seeds (right). Credits: Youngdoo-Licensed by CC BY 2.0 (https://search. creativecommons.org/photos/449b9820-987e-4faf-9b9941ae39c70a2f)

If starting seeds in containers, use a commercial seedstarting mix because it allows for optimum root growth and is free of pests and weeds. Make sure the container is clean and has drainage. Place containers in bright indirect light and keep soil evenly moist. Once the seedlings emerge, gradually increase the light level until it matches the garden area where they will be transplanted. Thin the seedlings to the recommended spacing (see Table 1) by snipping them off at the soil line. Pulling them out may damage the remaining seedlings.

Transplant when there are several sets of leaves and a well-developed root system. Plant at the same soil depth as they were growing in the container, and water frequently so the young transplants stay moist until established.

\section{Cuttings}

Certain herbs, such as sage, balm, and rosemary, are best propagated from cuttings. Stems from new growth or the upper parts of older stems root most easily. Cut the stems into 3-to-4-inch sections, each containing a set of leaves or leaf buds near the upper end. To prevent wilting, place the cuttings in water as soon as they are removed from the plant.

Choose a container that will drain well and fill it with a commercial soil mixture or a custom blend of equal parts clean sand, peat, and perlite. Consider treating cuttings with a rooting hormone labeled for use on edibles. Insert the cut end deep enough into the soil so that it stands upright on its own, then saturate the mix with water. Place in an area protected from the sun and keep moist (but not sopping wet). 
Cover the cuttings with clear plastic to hold in the humidity if consistent watering is a problem. Continue to water until the cuttings have developed a good root system and are ready to transplant to the garden or larger containers.

\section{Layering}

Trailing plants such as mint, thyme, winter savory, and marjoram can be propagated by simple layering, which consists of covering the lower portions of a side branch with soil, leaving the top exposed. When the covered part of the stem has rooted, it can be cut from the parent plant and established as an individual plant. Mint spreads rapidly by surface or underground runners that may grow several feet from the parent plant.

\section{Division}

Mature specimens of chives, lemongrass, mints, marjoram, and plants in the Zingiberaceae family can be multiplied by dividing the clumps into separate parts. These divisions can then be set as individual plants.

\section{Harvesting and Preserving}

The flavor of herbs and spices arises from the volatile or essential oils contained in them. The flavor is retained longer if the herbs are harvested at the right time and properly cured and stored. Young, tender leaves should be picked as needed (Figure 4) and used immediately. For later use, gather leaves in the morning and keep them moist and refrigerated.

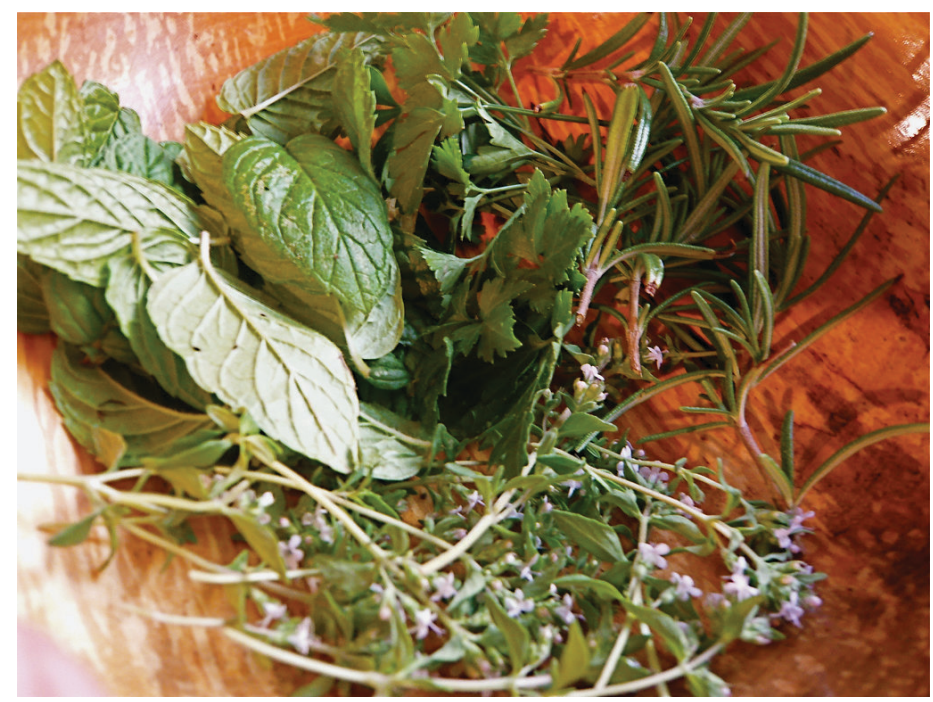

Figure 4. Harvested herbs.

Credits: WordRidden—Licensed by CC BY 2.0 (https://search. creativecommons.org/photos/305cc60b-94a2-4d67-9a9d9a0e80ef9ced)

If herbs are to be preserved, harvest them before the plants begin to flower and dry them in a well-ventilated, darkened room. If the leaves are dusty or gritty, wash them in cold water and thoroughly dry them. Tender-leaved herbs (e.g., basil, tarragon, lemon balm, and mints), which have a high moisture content, must be dried rapidly away from the light if they are to retain their green color. If dried too slowly, they will turn dark or moldy. For this reason, a well-ventilated, dark room furnishes ideal conditions for curing these herbs in a short time. Less-succulent leaf herbs (e.g., sage, rosemary, thyme, and summer savory) contain less moisture and can be partially dried in the sun without affecting their color, but excessive exposure should be avoided.

Some herbs (e.g., cilantro and dill) can be allowed to flower and set seed for kitchen use or replanting. Seeds should be harvested when they are mature or when their color changes from green to brown or gray. They should be thoroughly dry before storing to prevent loss of quality and viability.

As soon as leaves or seeds are dry, they should be cleaned by separating them from stems and other foreign matter and packed in air-tight containers to prevent loss of the essential oils that give herbs and spices their delicate flavor. Clear glass or plastic containers (Figure 5) should be painted or kept in a dark place to prevent light from bleaching the leaves. Tip: Fresh herbs can also be stored in the freezer. First clean, de-stem, and chop them. Then add them to ice cube trays with a small amount of water. Once frozen, remove the cubes from the tray and place them in a labeled freezer bag for later use in soups and stews.

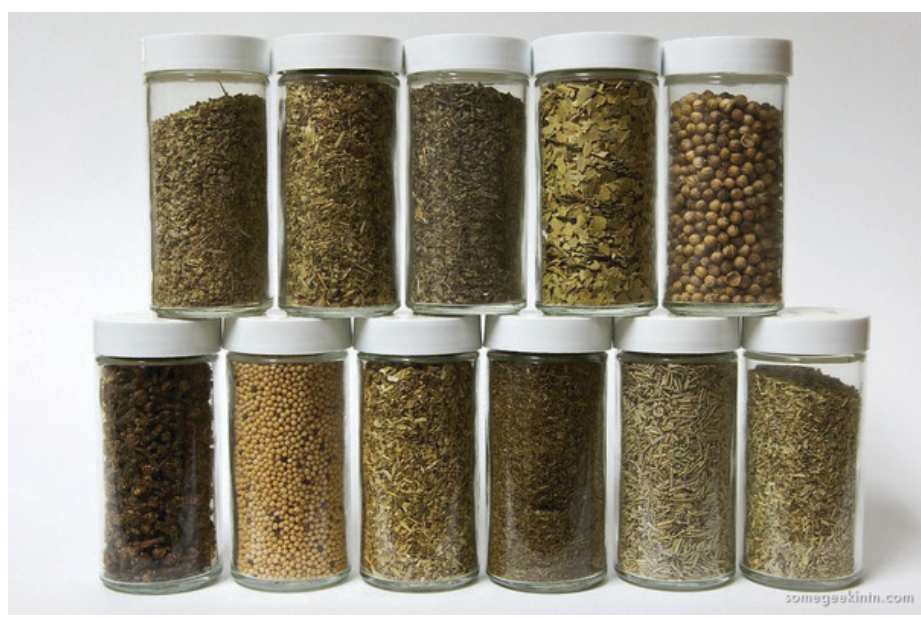

Figure 5. Herbs and spices in clear containers should be stored in the dark.

Credits: somgeekintn-Licensed by CC BY 2.0 (https://search. creativecommons.org/photos/2d227282-5516-4b52-8b79de9411bde1a7)

Herbs flavor foods without adding fat, sugar, or sodium. Recipes usually indicate the best time to add herbs to a dish, but a good rule of thumb is to mix herbs into hot 
dishes towards the end of the cooking time to preserve their flavor and aroma and add herbs to cold dishes as they are prepared. For more tips on cooking with herbs, see https:// edis.ifas.ufl.edu/publication/FY1209.

\section{Basil}

Basil (Ocimum spp.) is a fragrant warm-season herb with a spicy taste (Figure 6). There are many types of basil ranging in size, color, and taste. While sweet basil is the most commonly grown, varieties like Thai, purple, cinnamon, lemon, and others also exist. African blue basil produces abundant flowers that attract bees, but the plant's flavor is unappealing. Plant basil transplants or seeds from early spring through fall and pinch off and use the flavorful stem tips as it grows. This will encourage branching and more foliage. Remove any flower spikes that form or the leaves will lose flavor. The tender leaves may be used fresh at any time or dried. Basil prefers moist (not soggy) soil and occasional light applications of fertilizer. It is easy to root from cuttings. Basil Downy Mildew is a devastating fungus disease in Florida. Select disease-resistant cultivars such as 'Amazel Basil,' 'Pesto Besto', and others.

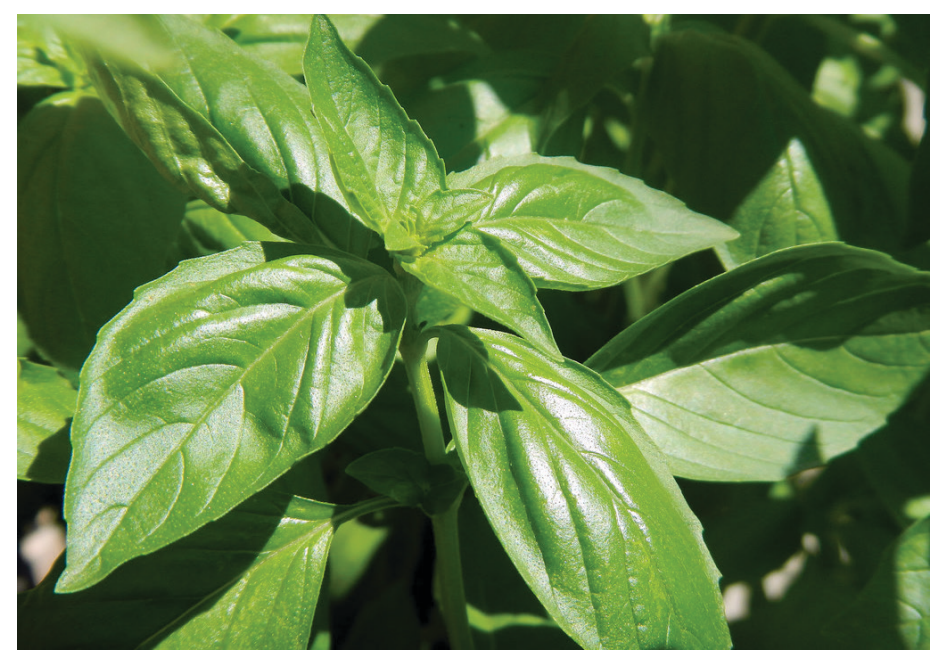

Figure 6. Basil.

Credits: Alice Henneman-Licensed by CC BY 2.0 (https://search. creativecommons.org/photos/ddc8a053-87b0-452b-95a5$41 \mathrm{e} 7 \mathrm{bdb} 3 \mathrm{~d} 5 \mathrm{fc}$ )

\section{Bay Leaf}

Bay leaf (Laurus nobilis) is a large evergreen shrub/small tree native to the Mediterranean that slowly grows to about 30 ' but can be kept smaller with pruning. Fresh or dried leaves are used for flavoring soups, stews, and other dishes but should be removed before serving. There are several trees commonly named "bay" in Florida, so when selecting the tree, verify the botanical name. Bay leaf can be grown throughout Florida (USDA Hardiness zones 8-10), although it is tender to cold and should be protected during a hard freeze. The dense growth habit makes it an attractive addition to the landscape.

\section{Borage}

Borage (Borago officinalis) is a cool-season annual in Florida with a cucumber-like odor and flavor. The leaves and pretty blue, star-like flowers are used in salads and beverages, and the plant is an attractive addition to a flower garden. The flowers are a favorite of bees. Plant in full to part sun and expect plants to grow to about 2 feet tall and wide. Once established, borage will self-sow from seeds for years to come. Additional benefits of this Mediterranean herb include deer and drought tolerance.

\section{Cardamom}

Cardamom (Elettaria cardamomum) is a tropical, perennial spice in the ginger family that forms huge 12' clumps of bold-textured foliage. The seeds are used to flavor and add aroma to coffee, candies, pastries, and other foods. Cardamom requires part shade, consistently moist conditions, and slightly acidic soil. Cardamom is best grown in south Florida in zones 10 and 11 where it will not be injured by cold. The plant dies back to the ground at $50^{\circ} \mathrm{F}$ and will not flower or set seed the following year. Small yellowish flowers are produced near the ground, which then form oblong ribbed seed capsules. These are harvested when green and then dried in the sun until they turn brown and split open.

\section{Chervil}

Chervil (Anthriscus cerefolium), also known as French parsley, is a cool-season annual grown for the anise-like flavor of its aromatic, fern-like leaves. Leaves should be picked as needed and used immediately to garnish salads, soups, egg dishes, sauces, and other foods. Some forms have thick roots eaten like carrots. Chervil grows best in full to part sun and rich, moist soil. Chervil can withstand cold but bolts (i.e., goes to seed) in warm weather and turns bitter when it flowers.

\section{Chives}

Onion chives (Allium schoenoprasum) are a perennial herb that can be enjoyed year-round in Florida. Expect chives to grow to about 12". Both the leaves and pink/ lavender flowers (Figure 7) are edible with a mild onion flavor. Garlic chives (Allium tuberosum) grow to 18" and have white flowers and a mild garlic flavor. Plant August through March from seed, sets, or divisions in full to part sun. Moist but well-drained soil is preferred. For a neat appearance, harvest a few leaves at a time at ground level to 
encourage new growth. Divide clumps every few years to revitalize them. Chives can also make an attractive addition to landscape beds.

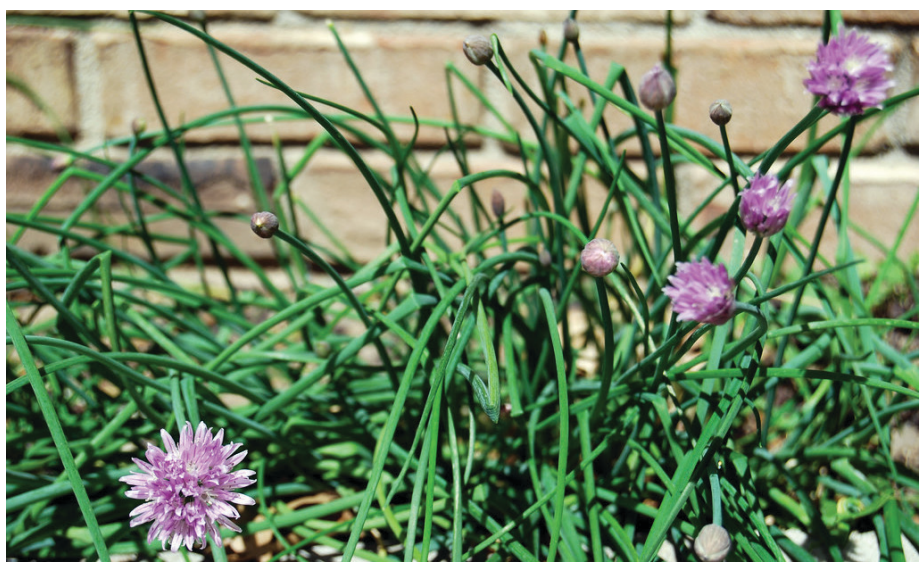

Figure 7. Chives.

Credits: Alice Henneman-Licensed by CC BY 2.0 (https://search. creativecommons.org/photos/a66d7c3c-0db2-4add-9e52-

f9db193bc1c9)

\section{Cilantro/Coriander}

Coriandrum sativum is a cool-season annual grown for its leaves (known as cilantro) and aromatic seeds (known as coriander). It is an attractive addition to a flower garden or landscape due to its feathery texture and pretty flowers. Seeds should be planted at 2-3 week intervals in well-drained, rich soil in fall, winter, or spring to ensure a continuous harvest. Warm temperatures cause it to quickly bolt, set seed, and die. Cilantro performs best when directseeded rather than transplanted. Cover seeds $1 / 4-1 / 2$ inch deep and thin plants $2 "-4$ " apart. After flowering, tiny fruits form and turn brown when mature. Harvest and dry them on a screen. Once dried, the seeds should be threshed from seed heads and stored in a dry, airtight container.

\section{Culantro}

Culantro (Eryngium foetidum) is a biennial herb indigenous to Latin America that is often grown as a summer annual in Florida. It is used to flavor salsa, sofrito, chutney, ceviche, sauces, rice, and soups. Culantro thrives under well-watered, shady conditions either planted in the ground or in a container. It belongs to the same plant family as cilantro but looks quite different. The long, tough leaves are similar to cilantro, but stronger-flavored, thus making it a respectable summer substitute for cilantro, which prefers cooler weather. To harvest, remove the oldest leaves at the base of the plant, leaving the young new leaves to grow. The leaves can be chopped and used fresh or frozen to keep their flavor. Small plants are sold in nurseries or they can be grown from seed. Seeds need light to germinate, so they must be scattered uncovered on soil, kept moist, and left undisturbed until they germinate in $2-3$ weeks. Culantro is a tender tropical plant that will be killed by frost or freezing temperatures. Cutting off the bloom stalk when it appears will delay flowering and encourage continued leafy growth.

\section{Cumin}

Cumin (Cuminum cyminum) is a warm-season annual that has delicate, thin foliage with masses of flowers in umbel-shaped flower heads. Grow cumin in full sun and water regularly, but allow the soil to dry between waterings. Cumin is not fussy about the soil type. Although some people harvest and eat the leaves, it is the pungent flavor of the ground seeds that is more widely appreciated. To harvest the seed, allow the pods (which form after flowering) to completely dry and turn brown. Rub the pods or hang stalks upside down to release the seed.

\section{Dill}

The young leaves and seeds of dill (Anethum graveolens) give dill pickles their name. It is an erect, strong-smelling, annual plant reaching a height of 4 feet. The yellow flowers (Figure 8) develop into fruits that can be used fresh or dried. Dill does best in mild weather, not too hot or cold, so plant in early fall and spring. Provide a sunny location and rich, well-drained soil. Fruiting tops may be used fresh or dried along with young leaves and portions of the stems. Be aware that the caterpillars of the black swallowtail butterfly feed on dill, fennel, and parsley, so you may want to plant a little extra.

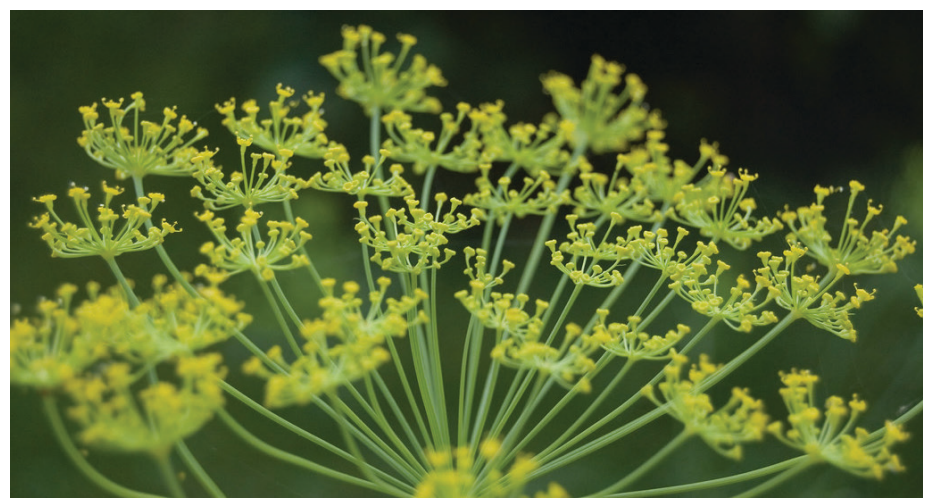

Figure 8. Dill flower head.

Credits: Denis Defrayne-Licensed under CC BY 2.0 (https:// search.creativecommons.org/photos/89db9afc-851b-43c7-94c6f76da4b49017)

\section{Fennel}

The common name "fennel" is confusing because there are two kinds. Common fennel (Foeniculum vulgare) is grown for its flavorful shoots, leaves, and seeds. Florence fennel (Foeniculum vulgare var. azoricum), also known as sweet fennel, bulbing fennel, and finocchio, is grown mainly for 
the thickened, bulbous leaf base, which is eaten raw or as a cooked vegetable. Except for the swollen, aboveground base of the leaves on Florence fennel, the two are very similar in appearance and in their licorice-like flavor. The plant resembles dill, with narrow, finely feathered leaves, bright yellowish-green hollow stems, and umbrella-like seed structures. In Florida, fennel grows best as a cool-season annual and can be harvested 3-4 months after planting. Bronze fennel is not only edible but also highly ornamental in the landscape.

\section{Garlic}

Garlic (Allium sativum) has been used throughout history in foods and medicinally. It grows underground as a compound bulb consisting of white cloves enclosed by white or purplish membranous skin. The aboveground leaves form a 12 -inch-tall clump. In Florida, soft-necked varieties are preferred because they need less cold to form bulbs. Garlic is propagated in late fall/early winter by dividing a bulb into cloves and planting them 2" deep and about 6" apart. Garlic does best in a sunny location with fertile well-drained soil; soggy soil will rot the bulbs. Harvest the bulbs when the leaves turn brown, and store them in a dry, cool area with plenty of air circulation.

\section{Ginger}

Many ornamental gingers grow in Florida, but the culinary species is Zingiber officinale. It is a perennial that produces well from south to north Florida. The thick, white, tuberous, underground rhizomes (Figure 9) are used in food and beverages, medicines, and personal-care products. Purchase fresh ginger at your local grocer and cut the rhizomes into 2-to-3-inch pieces with several emerging buds ("eyes"). Plant them about two inches deep in rich, moist soil in a shady area that gets some morning sun. The rhizomes are ready to harvest about 9-12 months after planting when the stalks die down in winter. Outer rhizomes can be harvested while leaving the remainder of the plant to grow and clump for the following years.

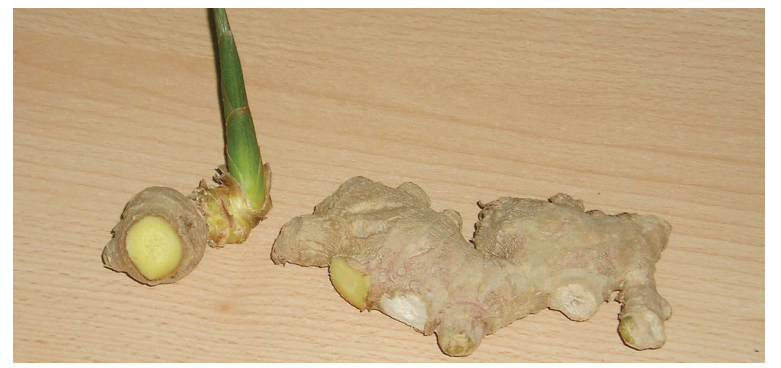

Figure 9. Ginger rhizome with sprouted eye. Credits: blumenbiene-Licensed CC BY 2.0 (https://search. creativecommons.org/photos/f17cd23e-bfb2-4faf-a45b60e04e3e92b1)

\section{Lavender}

Lavender (Lavandula spp.) has long been esteemed for the soothing fragrance it adds to soaps, lotions, oils, sachets, and fresh or dried bouquets. Increasingly lavender is also enjoyed for the subtle flavor it adds to pastries, sorbets, main dishes, jams, and many beverages. Lavender is native to the western Mediterranean, where the climate is mild and dry. Therefore, it grows best in Florida's cooler seasons. Numerous cultivars can be found at garden centers, but whichever type you choose, be sure to plant it in welldrained soil in full sun with plenty of air circulation. Water lightly during establishment; afterward minimal water and fertilizer are needed.

\section{Lemon Balm}

Lemon balm (Melissa officinalis) is a lemon-scented perennial herb belonging to the mint family. The plants grow in clumps 2 feet high with bright-green leaves (Figure 10). Plants are started from seeds or cuttings. Sow seeds shallowly in moist, fertile soil in early spring in a sunny location; space plants 18 inches apart. It may take two years before the plant forms a well-sized clump. Leaves and tender stems are used fresh or dried to flavor drinks, salads, or other dishes.

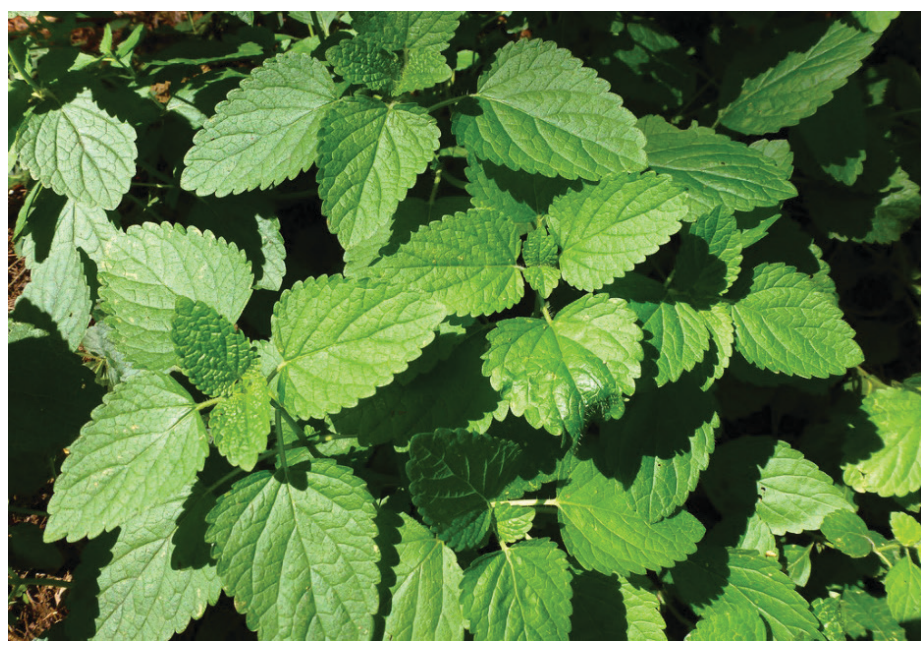

Figure 10. Lemon balm.

Credits: Wendell Smith—Licensed by CC BY 2.0 (https://search. creativecommons.org/photos/733b2a26-aa5c-4b14-9789$82110170 \mathrm{e} 3 \mathrm{~b} 6)$

\section{Lemongrass}

Lemongrass (Cymbopogon citratus) is a tender perennial clumping grass (Figure 11). It has a pleasant lemony aroma and is used in cooking, teas, herbal medicines, home products, and personal-care products. The thick stalks at the base of the plant and the leaves are harvested for use. Lemongrass is also enjoyed as a fragrant landscape plant. It grows to 6 feet and turns scarlet in the fall. Plant in full sun 
in rich soil with regular irrigation, because it does not like to dry out. Propagation is by division.

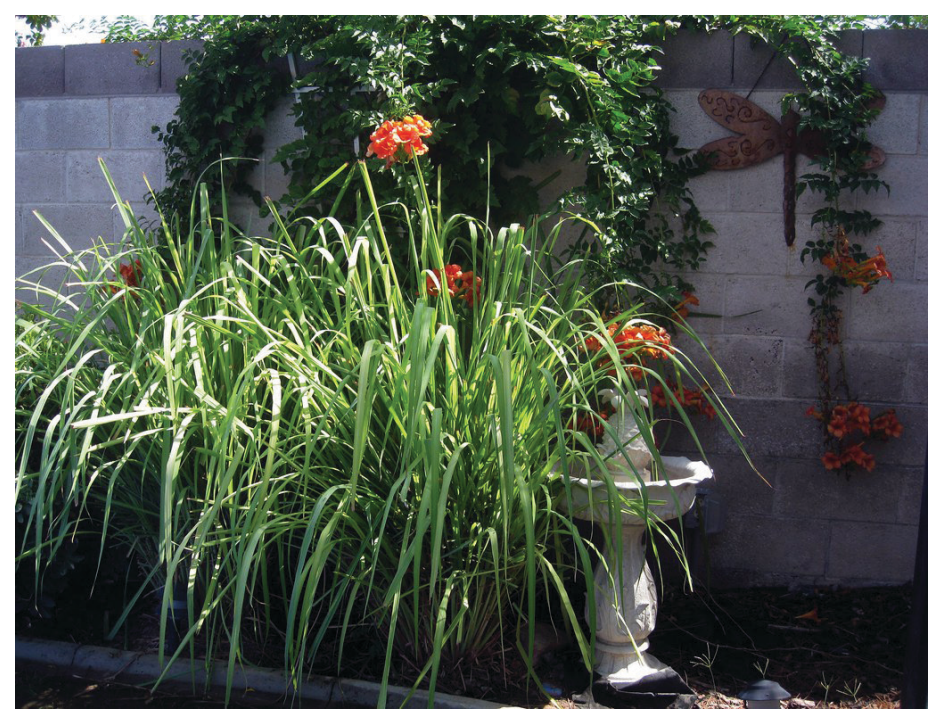

Figure 11. Lemongrass.

Credits: odonata98 - Licensed by CC BY-ND 2.0 (https://search. creativecommons.org/photos/a9b4b4df-79c6-4109-91f8b2a4485f52b9)

\section{Marjoram}

Marjoram is often grown as a summer annual in north Florida and a winter annual in south Florida. It's delicately flavored and is used in cooking, herbal medicines, and as décor when dried. There are three kinds of marjoram commonly used as herbs: sweet marjoram (Origanum marjorana), pot marjoram (O. onites), and wild marjoram (O. vulgare). Sweet and pot marjoram are usually grown in herb gardens. They are very similar, except sweet marjoram tends to grow upright while pot marjoram runs along the ground. Space pot marjoram about 12 inches apart, and sweet marjoram 6 inches apart. Plants can be started early in the spring from seeds, cuttings, or clump divisions. Marjoram does best in full sun and rich, well-drained soil. The leaves are used fresh or dried. Marjoram is sufficiently attractive to make an excellent border planting for a flower garden.

\section{Mint}

Mints (Mentha spp.) are easy-to-grow perennial herbs for Florida gardens (Figure 12). Hundreds of varieties and cultivars provide a wide range of flavors. Spearmint (Mentha spicata) and peppermint (M. piperita) are two of the more popular, along with apple, chocolate, and orange mints. Mint is used in beverages, foods, and personal-care products, and as an insect repellent. Leaves vary but generally are dark green, small, and pointed, with slightly notched margins. Small flowers are whitish, bluish, or violet. Mint can be started from rooted runners, divisions, or small potted plants. In Florida, mints grow profusely in shade or full sun and like plenty of moisture. The leaves and flowering tops are used, both fresh and dried. Mint is an aggressive spreader and is best grown where it can be contained.

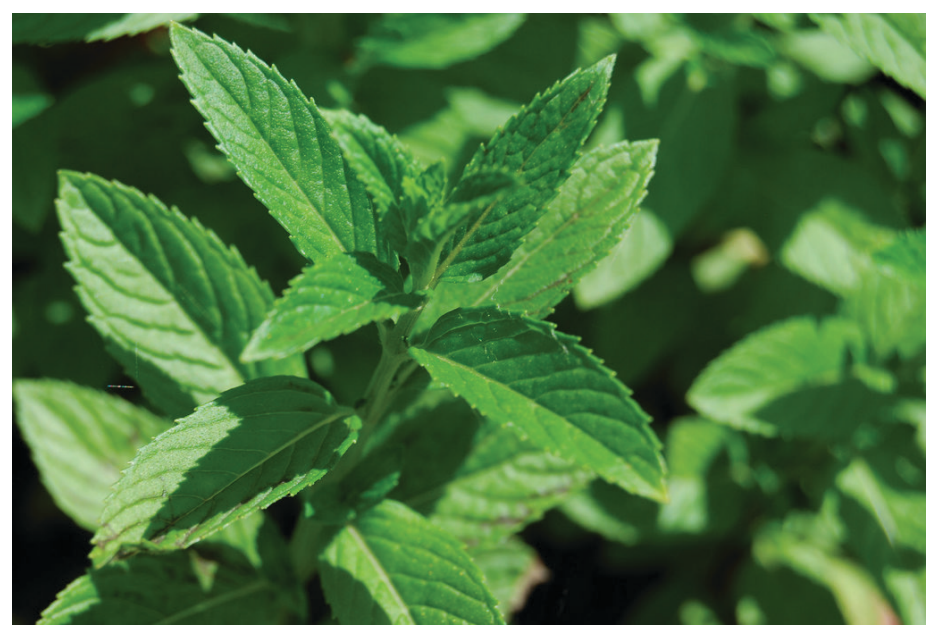

Figure 12. Mint.

Credits: Alice Henneman—Licensed by CC BY 2.0 (https://search. creativecommons.org/photos/01a185f8-168c-47a7-b55104ce1404ebd2)

\section{Oregano}

There are two main types of oregano: Mexican (Lippia graveolens) and European (Origanum spp.). Mexican oregano has an earthy, strong flavor with citrus notes; European oregano is much milder. Plant in full sun in sandy loamy soil; it is drought tolerant once established. If grown in frost-free regions, it can become a 5-foot-tall woody shrub after a few years. European oreganos are usually found as Italian, Greek, or Golden oregano, and they vary in taste. Oregano is a tender perennial and is killed by frost. It may be grown from seed sown in the spring or propagated by cuttings. Regular harvesting of the leaf tips promotes a fuller and more compact habit.

\section{Parsley}

Parsley (Petroselinum crispum) is officially a biennial, although it typically grows as a cool-season annual in Florida. Planted in the fall, parsley typically thrives in cool weather and then flowers, produces seeds, and dies in late spring/early summer. Growing it in light shade will prolong its life, but it will flower and die eventually. Flat-leafed (Italian) parsley (Figure 13) is valued for flavoring, whereas the curly-leaf type is used more as a garnish. Root parsley (Petroselinum crispum var. tuberosum) has white roots that look like young parsnips and is used as a cooked vegetable, particularly in soups. Parsley grows best in full sun or partial shade and prefers rich, moist soil. 


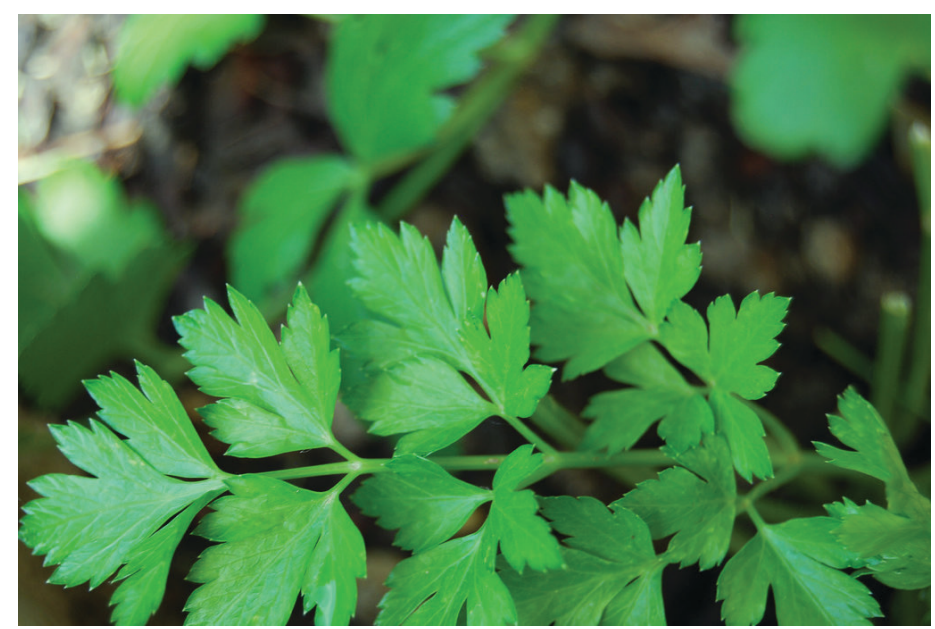

Figure 13. Italian flat-leaf parsley.

Credits: Alice Henneman-Licensed by CC BY 2.0 (https://search. creativecommons.org/photos/1c5683cb-c246-4eeb-8afbdc95202f6313)

\section{Rosemary}

Rosemary (Rosmarinus officinalis) (Figure 14) is a perennial, 2'-3', evergreen shrub with a spicy aroma. The small, narrow, green leaves are used fresh or dried in many cuisines. Small lavender flowers form in the second or third year. Rosemary is difficult to propagate from seeds, so it is best to start with cuttings or a purchased plant. Once established, rosemary is drought and salt tolerant and grows well in sunny, dry locations. It will suffer from overwatering and shade. Rosemary can be enjoyed as an attractive lowmaintenance shrub in a water-wise or coastal landscape.

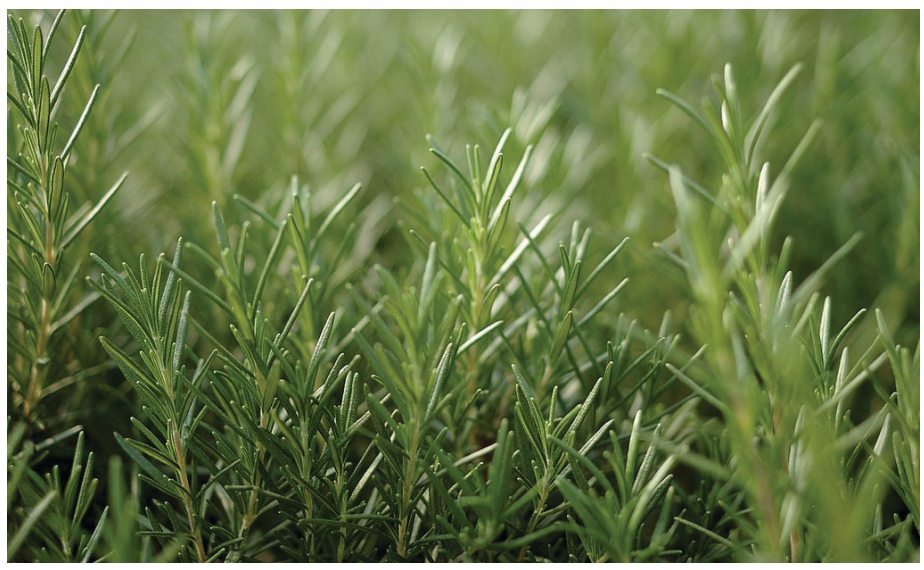

Figure 14. Rosemary.

Credits: Vincent Gallary—Licensed by CC BY 2.0 (https://search. creativecommons.org/photos/66092eeb-26df-4991-b9eb90e36845309e)

\section{Sage}

Sage (Salvia officinalis) is a short-lived perennial that grows to about 2' with grayish-green leaves (Figure 15). The fragrant purple flowers generally do not appear until the second year and are very attractive to bees and butterflies. However, if using sage as a culinary herb, trim the tips of the branches to prevent flowering, which will maintain the optimal flavor of the leaves. Leaves are used fresh or dried. In the landscape, sage is an attractive, low-growing border plant. Plant sage in full sun in well-drained soil.

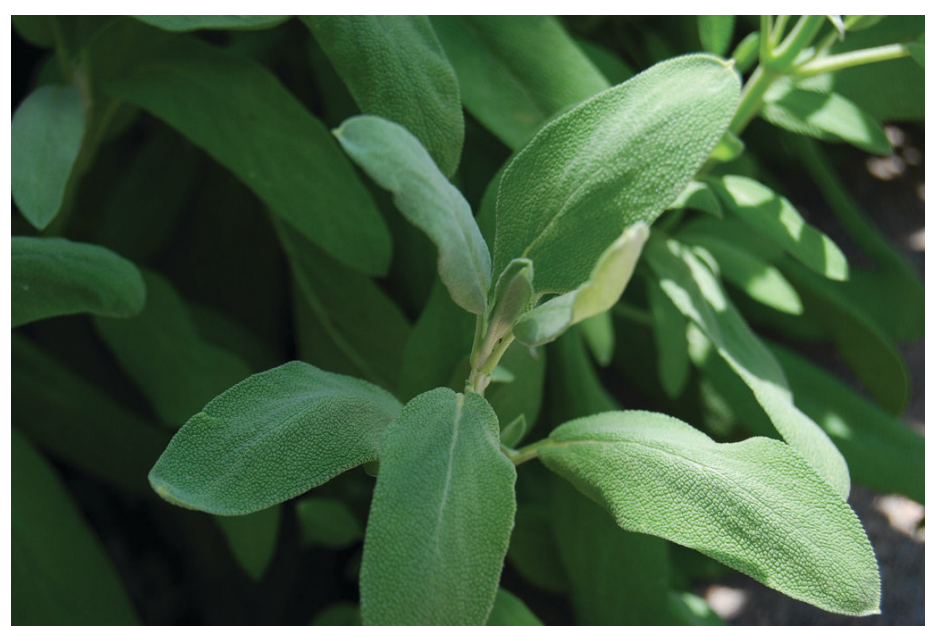

Figure 15. Sage.

Credits: Alice Henneman—Licensed by CC BY 2.0 (https://search. creativecommons.org/photos/504ccabf-9977-4538-834c12974c7885b2)

\section{Savory}

Savory is classified as summer savory (Satureja hortensis) or winter savory (Satureja montana). Both species of savory have leaves with a strong peppery flavor, although winter savory is more pungent. Summer savory is a warm-season annual, while winter savory is a perennial shrub. Plants may be difficult to find in nurseries but can be grown from seed. Plant in full sun in rich, well-drained soil for best results. Keep the stem tips of savory trimmed to prevent flowering, because the leaves turn brown after flowering. The zesty, peppery-tasting leaves are used fresh or dried.

\section{Tarragon}

French tarragon (Artemisia dracunculus var. sativa) is a difficult herb to grow in Florida because it tends to die out in our summer heat and humidity. It can only be propagated by cuttings because the infrequent flowers are sterile and do not produce seed. Tarragon seed offered for sale is often Russian tarragon (Artemisia dracunculoides), which has a similar taste. Mexican tarragon (Tagetes lucida) has an anise-like flavor and can also serve as a substitute for French tarragon. Mexican tarragon is native to the southwest United States and Mexico and is tolerant of Florida's hot, humid summers. 


\section{Thyme}

Thyme (Thymus vulgaris) is a shrubby perennial herb with tiny gray-green leaves (Figure 16). Purplish flowers are formed at the ends of the stems. Some varieties are creeping while others grow upright to 18 inches. Lemon thyme is a variety that adds lemon flavor and aroma. Plant in full sun and well-drained soil. Thyme is drought tolerant. Replant thyme every three to four years for best growth because it tends to get woody. Thyme leaves and flowers can be used fresh or dried.

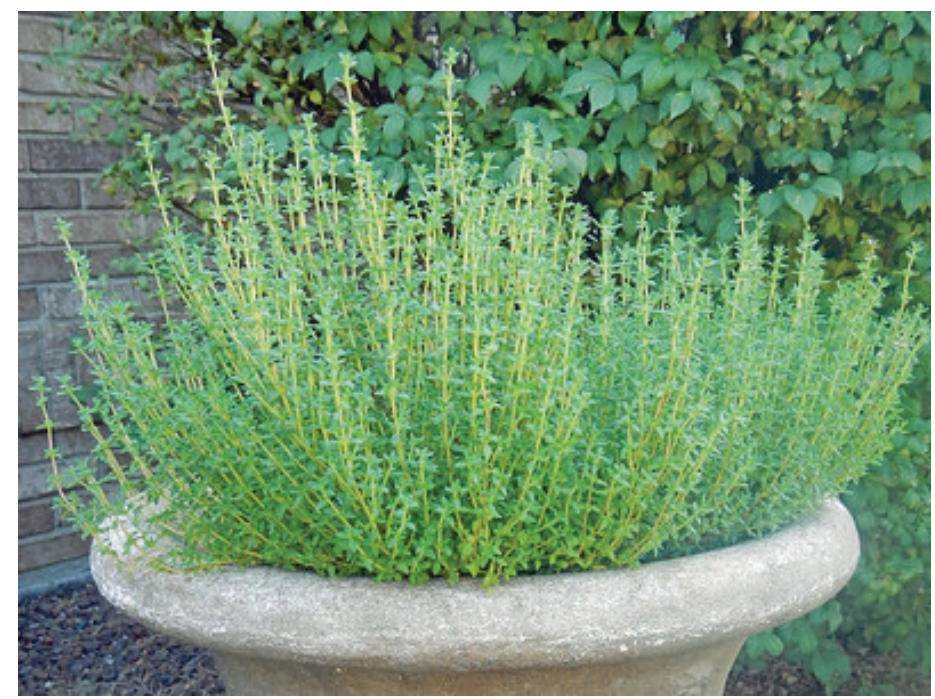

Figure 16. Thyme growing in a container.

Credits: Alice Henneman-Licensed by CC BY 2.0 (https://search. creativecommons.org/photos/79d42922-e7d6-43a9-961a4ba1a5fofa90)

\section{Turmeric}

Turmeric (Curcuma longa), a member of the ginger family, thrives in the warm, moist conditions of Florida. The spice it yields is derived from the rhizomatous roots that are used fresh, or dried and ground into a yellow-orange powder. The flavor of turmeric is described as warm, earthy, and black-pepper-like. It is commonly used in many Asian dishes and also as a dye. In Florida, turmeric grows as an attractive, 3-foot-tall, tropical perennial that produces attractive white flowers. The foliage dies to the ground in winter and reemerges in spring. Plants can be purchased at garden centers or started from rhizomes found in the produce section of some grocery stores. Cut or break up rhizomes into 1-2 inch pieces with emerging buds ("eyes"), and plant them 1 inch deep in pots or directly into the garden in a shady spot. Homegrown rhizomes are harvested in late fall or winter after the foliage dies back. Break up the "hands" and allow them to dry for a day or two. Freeze them or store at room temperature in a bucket of dry playground sand to use as needed during winter. Save a few to replant in the ground or in large pots the following spring.

\section{Acknowledgments}

The authors wish to thank the following contributors:

Kathy Warner, Nassau County Master Gardener volunteer: Katherine Oliver, program assistant in residential horticulture, UF/IFAS Extension Manatee County; and Beth Bolles, horticulture agent, UF/IFAS Extension Escambia County. 
Table 1. Herbs and Spices in the Florida Garden

\begin{tabular}{|c|c|c|c|c|c|}
\hline $\begin{array}{c}\text { Herb } \\
\text { (Plant Family) }\end{array}$ & $\begin{array}{l}\text { Growth Cycle } \\
\text { in Florida }\end{array}$ & Propagation & Spacing & Part Used & Harvest \\
\hline Basil (Lamiaceae) & warm-season annual & seed, cuttings & $4^{\prime \prime}-12^{\prime \prime}$ & leaves & as needed \\
\hline Bay Lea (Lauraceae) & evergreen shrub/tree & cuttings & $\begin{array}{l}\text { depends on size/ } \\
\text { pruning }\end{array}$ & leaves & as needed \\
\hline $\begin{array}{l}\text { Borage } \\
\text { (Boraginaceae) }\end{array}$ & cool-season annual & seed & $4 "-12^{\prime \prime}$ & flowers & as needed \\
\hline $\begin{array}{l}\text { Cardamom } \\
\text { (Zingiberaceae) }\end{array}$ & perennial & division & $18^{\prime \prime}$ & seeds & when pods are green \\
\hline Chervil (Apiaceae) & cool-season annual & seed & $12^{\prime \prime}$ & leaves & as needed \\
\hline $\begin{array}{l}\text { Chives } \\
\text { (Amaryllidaceae) }\end{array}$ & perennial & seed/division & $8^{\prime \prime}$ & leaves & as needed \\
\hline $\begin{array}{l}\text { Cilantro/Coriander } \\
\text { (Apiaceae) }\end{array}$ & cool-season annual & seed & $12^{\prime \prime}$ & $\begin{array}{l}\text { leaves } \\
\text { seeds }\end{array}$ & $\begin{array}{l}\text { as needed } \\
\text { when ripe }\end{array}$ \\
\hline Culantro (Apiaceae) & $\begin{array}{l}\text { warm-season annual } \\
\text { or biennial }\end{array}$ & seed & $6^{\prime \prime}$ & leaves & as needed \\
\hline Cumin (Apiaceae) & warm-season annual & seed & $6^{\prime \prime}-8^{\prime \prime}$ & $\begin{array}{l}\text { leaves } \\
\text { seeds }\end{array}$ & $\begin{array}{l}\text { as needed } \\
\text { when ripe }\end{array}$ \\
\hline Dill (Apiaceae) & cool-season annual & seed & $12^{\prime \prime}$ & $\begin{array}{l}\text { leaves } \\
\text { seeds }\end{array}$ & $\begin{array}{l}\text { as needed } \\
\text { when ripe }\end{array}$ \\
\hline Fennel (Apiaceae) & cool-season annual & seed & $12^{\prime \prime}$ & $\begin{array}{l}\text { leaves } \\
\text { seeds }\end{array}$ & $\begin{array}{l}\text { as needed } \\
\text { when ripe }\end{array}$ \\
\hline $\begin{array}{l}\text { Garlic } \\
\text { (Amaryllidaceae) }\end{array}$ & cool-season annual & cloves & $6 "$ & bulb & when mature \\
\hline $\begin{array}{l}\text { Ginger } \\
\text { (Zingiberaceae) }\end{array}$ & perennial & root division & $24^{\prime \prime}$ & rhizome & when mature \\
\hline Lavender (Lamiaceae) & cool-season annual & cuttings & $24^{\prime \prime}$ & leaves flowers & as needed \\
\hline $\begin{array}{l}\text { Lemon balm } \\
\text { (Lamiaceae) }\end{array}$ & perennial & seed/cuttings & $12^{\prime \prime}$ & leaves & as needed \\
\hline $\begin{array}{l}\text { Lemongrass } \\
\text { (Poaceae) }\end{array}$ & perennial & seed/division & $24 "$ & leaves & as needed \\
\hline $\begin{array}{l}\text { Marjoram } \\
\text { (Lamiaceae) }\end{array}$ & perennial & seed/cuttings & $12^{\prime \prime}$ & leaves & as needed \\
\hline Mint (Lamiaceae) & perennial & cuttings/division & $12^{\prime \prime}$ & leaves & as needed \\
\hline Oregano (Lamiaceae) & perennial & division & $24^{\prime \prime}$ & leaves & dry leaves \\
\hline Parsley (Apiaceae) & $\begin{array}{l}\text { biennial, grown as } \\
\text { cool-season annual }\end{array}$ & seed & $12^{\prime \prime}$ & leaves & as needed \\
\hline $\begin{array}{l}\text { Rosemary } \\
\text { (Lamiaceae) }\end{array}$ & perennial & cuttings & $24 "$ & leaves & as needed \\
\hline Sage (Lamiaceae) & perennial & seed/cuttings & $24^{\prime \prime}$ & leaves & as needed \\
\hline Savory (Lamiaceae) & annual/perennial & seed & $12^{\prime \prime}$ & leaves & as needed \\
\hline Tarragon (Asteraceae) & cool-season annual & seed/cuttings & $24^{\prime \prime}$ & leaves & as needed \\
\hline Thyme (Lamiaceae) & perennial & seed/cuttings & $12^{\prime \prime}$ & leaves flowers & as needed \\
\hline $\begin{array}{l}\text { Turmeric } \\
\text { (Zingiberaceae) }\end{array}$ & perennial & root division & $24^{\prime \prime}$ & rhizome & when mature \\
\hline
\end{tabular}

